\title{
Perbedaan Glasgow Coma Scale dan Rapid Emergency Medicine Score dalam Memprediksi Outcome Pasien Trauma Kepala di Instalasi Gawat Darurat
}

\author{
Difference between Glasgow Coma Scale and Rapid Emergency Medicine \\ Score in Predicting Outcome of Head Trauma Patients in the Emergency \\ Departement
}

Didik Mulyono

Instalasi Gawat Darurat Rumah Sakit Paru Manguharjo Madiun, Jawa Timur, Indonesia

\section{ARTICLE INFO}

\section{Article history}

Received date

24 July 2020

Revised date

19 August 2020

Accepted date

07 Sept 2020

Keywords:

Emergency Departement; GCS;

Outcome of head trauma patients;

REMS.

Kata kunci:

IGD;

GCS;

Outcome pasien trauma kepala;

REMS.

\begin{abstract}
ABSTRAK
Initial assessment of patients with head trauma is an influence on the management of patients with head trauma. GCS was developed to describe the level of consciousness in patients with head trauma. Whereas REMS is a scoring system that has been used widely in various countries to predict the mortality of patients coming to the emergency room. The purpose of this study was to determine the differences in the effectiveness of REMS and GCS scoring on the outcome of head trauma patients in the Emergency Departement. This study uses an analytic observational design with a retrospective cohort approach. The sample consisted of 181 patients where the sampling was carried out using a purposive sampling technique in which the researchers selected samples according to the inclusion and exclusion criteria of the existing population. Bivariate analysis conducted in this study used the Somers'd test and the Spearman test. The Area Under Receiver Operating Characteristics (AUROC) is used to assess the ability of REMS and GCS scoring to distinguish good outcomes and bad outcomes. The results of this study indicate that REMS and GCS scoring has a p-value $<0,05$ which means there is a significant relationship with the outcome of head trauma patients. From the results of the AUROC analysis, the AUC value was 0.753 for REMS, and the AUC was 0.769 for GCS. The ability of REMS and GCS to predict the outcome of head trauma patients shows good performance. So that both can be considered used as an early detection system or Early Warning Score System (EWSS) in head trauma patients in the Emergency Departement.
\end{abstract}

Penilaian awal pasien dengan trauma kepala merupakan hal yang berpengaruh pada penatalaksanaan pasien dengan trauma kepala. GCS dikembangkan untuk menggambarkan tingkat kesadaran pada pasien dengan trauma kepala. Sedangkan REMS merupakan suatu sistem skor yang telah digunakan secara luas di berbagai negara untuk memprediksi mortalitas pasien yang datang ke IGD. Tujuan dari penelitian ini adalah untuk mengetahui perbedaan efektifitas scoring REMS dan GCS terhadap outcome pasien trauma kepala di IGD. Penelitian ini menggunakan design observasional analitik dengan pendekatan kohort retrospektif. Sampel berjumlah 181 pasien dimana pengambilan sampel dilakukan menggunakan teknik purposive sampling dimana peneliti memilih sampel sesuai kriteria inklusi dan eksklusi dari populasi yang ada. Analisis bivariat yang dilakukan pada penelitian ini menggunakan uji somers'd dan uji spearman. The Area Under Receiver Operating Characteristic (AUROC) digunakan untuk menilai kemampuan scoring REMS dan GCS membedakan outcome baik dan outcome buruk. Hasil dari penelitian ini menunjukkan scoring REMS dan GCS memiliki p-value $<0,05$ yang berarti ada hubungan yang signifikan dengan outcome pasien trauma kepala. Dari hasil analisis AUROC didapatkan nilai AUC sebesar 0,753 untuk REMS, dan AUC sebesar 0,769 untuk GCS. Kemampuan REMS dan GCS memprediksi outcome pasien trauma kepala menunjukkan performa baik. Sehingga keduanya bisa dipertimbangkan digunakan sebagai sistem deteksi dini atau Early Warning Score Sistem (EWSS) pada pasien trauma kepala di IGD.

Corresponding Author:

Didik Mulyono

Rumah Sakit Paru Manguharjo Madiun, Jawa Timur, Indonesia

Email: mzdidik79@gmail.com 


\section{PENDAHULUAN}

Trauma kepala berkontribusi hingga $30 \%$ dari semua kematian terkait cedera dan merupakan penyebab utama kecacatan pada mereka yang masih bertahan hidup (Saiegh, et al., 2020). Pasien dengan trauma kepala mengalami sequelae atau gejala sisa yang berdampak pada individu, keluarga maupun sosial. Sequelae ini sangat heterogen, terdiri dari defisit kognitif, gangguan kejiwaan, gangguan motorik dan sensorik, epilepsi, dan lainnya (De Oliveira Thais, et al., 2014). Outcome pasien trauma tergantung pada tingkat keparahan, ketepatan penilaian awal dan waktu untuk mencapai tempat pertolongan perawatan. Penilaian yang cepat dan tepat dapat menurunkan angka kematian dan kecacatan jangka panjang (Miller, Nazir, McDonald, \& Cannon, 2017).

Penilaian awal pasien dengan trauma merupakan hal yang berpengaruh pada penatalaksanaan pasien dengan trauma kepala. Mortalitas dapat menurun jika pasien trauma kepala segera dilakukan penilaian untuk mendapatkan penanganan yang tepat di rumah sakit (Mulyono, Nurdiana, \& Kapti, 2019).

$$
\text { Glasgow Coma Scale }
$$

(GCS) dikembangkan untuk menggambarkan tingkat kesadaran pada pasien dengan trauma kepala. Skala ini dibuat terutama untuk menilai keparahan disfungsi otak. GCS mengukur respons mata, motorik, dan verbal pasien trauma kepala dan merupakan skala prognostik yang digunakan dan diterima secara luas baik untuk menilai tingkat kesadaran pada pasien trauma maupun non-trauma (Lecky, Roberts, \& Maas, 2017). GCS juga telahdiakui sebagai alat yang dapat diandalkan untuk memantau pasien dengan trauma kepala dan untuk mengidentifikasi perburukan kondisi. GCS juga merupakan indeks keparahan cedera karena skor ini berhubungan dengan outcome (In-suk, Hyoung-joon, Hyeongjoong, \& Kyu-sun, 2020). Nilai prognostik dari GCS telah dipelajari secara luas pada pasien dengan trauma kepala. GCS yang lebih rendah telah terbukti terkait dengan hasil yang lebih buruk dan hubungan terbalik, antara angka kematian dan jumlah telah dilaporkan pada pasien dengan trauma kepala (Teasdale, et al., 2014).

Rapid Emergency Medicine Score (REMS) merupakan suatu sistem skor yang telah digunakan secara luas di berbagai negara untuk memprediksi mortalitas pasien yang datang ke IGD. REMS dihitung berdasarkan GCS, pernapasan, saturasi oksigen, Mean Arterial
Pressure (MAP), nadi dan usia (Park, et al., 2017). Skoring ini sudah terbukti menjadi penduga kematian yang mudah dan akurat di rumah sakit pada pasien trauma (Imhoff, et al., 2014). Penelitian yang dilakukan oleh Nakhjavan-shahraki, et al (2017) menyebutkan bahwa REMS memiliki nilai prediktif sangat kuat terhadap mortalitas dan perburukan outcome pada pasien trauma yang datang ke IGD. Nilai Area Under Curve (AUC) dari REMS dalam memprediksi kematian di rumah sakit didapatkan 0,93 (95\% CI: 0,92-0,95) (Nakhjavan-shahraki, et al., 2017). Hasil yang hampir sama juga didapatkan dari hasil penelitian Park, et al (2017), diskriminasi REMS pada pasien dengan trauma didapatkan nilai AUC sebesar 0,9, ini berarti bahwa REMS sangat baik memprediksi outcome pasien trauma (Park, et al., 2017).

Penilaian awal menggunakan REMS merupakan penilian awal yang mempertimbangkan status neurologis sekaligus status fisiologis. Sementara GCS yang merupakan standart baku pengukuran derajat trauma kepala telah dipakai sebagai instrumen pemeriksaan awal ini hanya menilai status neurologis, belum mempertimbangkan status fisiologisnya. Berdasarkan hal-hal di atas, maka tujuan penelitian ini untuk mengetahui perbedaan efektifitas scoring REMS dan GCS terhadap outcome pasien trauma kepala.

\section{METODE}

Penelitian ini menggunakan desain observasional analitik dengan pendekatan kohort retrospektif di RSUD dr. Soedono Madiun pada bulan Maret 2019. Ada 181 data rekam medis dipilih berdasarkan kriteria inklusi dan ekslusi. Pengambilan sampel dilakukan menggunakan teknik purposive sampling dimana peneliti memilih sampel sesuai dengan yang dikehendaki peneliti, yakni yang memenuhi kriteria inklusi dan eksklusi dari populasi yang ada. Analisis bivariat mengunakan uji spearman untuk mengetahui hubungan GCS dengan outcome dan uji somers' $d$ untuk mengetahui hubungan REMS dengan outcome. The Area Under Receiver Operating Characteristic (AUROC) digunakan untuk menilai kemampuan REMS membedakan outcome baik dan outcome buruk.

Penelitian ini telah mendapat persetujuan etik dari Komisi Etik Penelitian Kesehatan Fakultas Kedokteran Universitas Brawijaya dengan nomor: 89/EC/KEPK-S2/03/2019. 
Tabel 1. Rapid Emergency Medicine Score (REMS) Scoring System

Ket:

\begin{tabular}{|c|c|c|c|c|c|c|c|}
\hline \multirow{2}{*}{ Variabel } & \multicolumn{7}{|c|}{ Score } \\
\hline & $\mathbf{0}$ & 1 & 2 & 3 & 4 & 5 & 6 \\
\hline Umur (Tahun) & $<45$ & & $45-54$ & $55-64$ & & $65-74$ & $>74$ \\
\hline $\mathbf{P R}(/ \min )$ & $70-109$ & & $\begin{array}{r}55-69 \\
110-139\end{array}$ & $\begin{array}{r}40-54 \\
140-179\end{array}$ & $\begin{array}{r}\leq 39 \\
>179\end{array}$ & & \\
\hline MAP(mmHg) & 70-109 & & $\begin{array}{r}50-69 \\
110-129\end{array}$ & $130-159$ & $\begin{array}{r}\leq 49 \\
>159\end{array}$ & & \\
\hline $\mathbf{R R}(/ \mathbf{m i n})$ & $12-24$ & $\begin{array}{l}10-11 \\
25-34\end{array}$ & $6-9$ & $35-49$ & $\begin{array}{r}\leq 5 \\
>49\end{array}$ & & \\
\hline $\begin{array}{l}\text { GCS } \\
\text { SpO2 }(\%)\end{array}$ & $\begin{array}{r}14 \text { or } 15 \\
>89\end{array}$ & $\begin{array}{l}11-13 \\
86-89\end{array}$ & $8-10$ & $\begin{array}{r}5-7 \\
75-85\end{array}$ & $\begin{array}{r}3 \text { or } 4 \\
<75\end{array}$ & & \\
\hline
\end{tabular}

PR : Pulse Rate; MAP: Mean Arterial Pressure; RR: Respirasi Rate; GCS: Glasgow Coma Scale; SpO2; peripheral oxygen saturation; Sumber: (Olsson, Terent, \& Lind, 2004).

\section{HASIL}

Tabel 2. Karakteristik Subjek Penelitian

\begin{tabular}{llrr}
\hline Variabel & Klasifikasi & n & \% \\
\hline Jenis & Laki-Laki & 128 & 71 \\
Kelamin & Perempuan & 53 & 29 \\
\hline \multirow{4}{*}{ Usia } & $16-25$ & 41 & 23 \\
& $26-35$ & 21 & 12 \\
& $36-45$ & 20 & 11 \\
& $46-55$ & 37 & 20 \\
& $56-65$ & 36 & 20 \\
& $>65$ & 26 & 14 \\
\hline \multirow{4}{*}{ Pendidikan } & Tidak Sekolah & 1 & 1 \\
& SD & 71 & 39 \\
& SLTP & 25 & 14 \\
& SLTA & 72 & 40 \\
& PT & 12 & 7 \\
\hline \multirow{5}{*}{ Pekerjaan } & Tidak Bekerja & 19 & 10 \\
& Pedagang & 4 & 2 \\
& Karyawan Swasta & 66 & 36 \\
& Wiraswasta & 8 & 4 \\
Trauma & Petani & 45 & 25 \\
& PNS/TNI/POLRI & 9 & 5 \\
& Pelajar/Mahasiswa & 30 & 17 \\
\hline Penyebab & Kecelakaan Lalu & 155 & 86 \\
& Lintas & 26 & 14 \\
\hline & Terjatuh & &
\end{tabular}

Tabel 2 menunjukkan sebagian besar berjenis kelamin laki-laki sebanyak 128 orang (71\%). Berdasarkan karakteristik usia, usia responden terbanyak dengan persentase $23 \%$ adalah kelompok usia 16-26 tahun. Berdasarkan karakteristik pendidikan, bahwa hampir setengah responden yakni sebesar $40 \%$ dengan tingkat pendidikan SLTA. Pekerjaan responden sebanyak $36 \%$ dari total responden adalah karyawan swasta. Penyebab trauma kepala, hampir seluruhnya yakni $86 \%$ adalah kecelakaan lalu lintas.
Tabel 3. Distribusi Frekuensi Responden Berdasarkan Hasil Scoring REMS

\begin{tabular}{lrr}
\hline \multicolumn{1}{c}{ Scoring REMS } & \multicolumn{1}{c}{ n } & \multicolumn{1}{c}{$\%$} \\
\hline Risiko Rendah (Skor < 5) & 71 & 39 \\
Risiko Sedang (Skor 5-13) & 107 & 59 \\
Risiko Tinggi (Skor >13) & 3 & 2 \\
\hline
\end{tabular}

Tabel 3 menunjukkan bahwa sebagian besar yaitu sebesar 59\% termasuk dalam klasifikasi risiko sedang, sedangkan sebagian kecil responden sebesar $2 \%$ masuk klasifikasi risiko tinggi.

Tabel 4. Distribusi
$\begin{array}{crr}\text { Ferdasarkan Hasil Skor GCS } \\
\text { Berdansi }\end{array}$
\begin{tabular}{crr} 
Skor GCS & n & \% \\
\hline 3 & 18 & 9,9 \\
4 & 4 & 2,2 \\
5 & 18 & 9,9 \\
6 & 11 & 6,1 \\
7 & 19 & 10,5 \\
8 & 26 & 14,4 \\
9 & 24 & 13,3 \\
10 & 14 & 7,7 \\
11 & 23 & 12,7 \\
12 & 24 & 13,3 \\
\hline
\end{tabular}

Tabel 4 memperlihatkan responden terbanyak memiliki skor GCS 8 atau dalam klasifikasi cedera kepala berat yaitu sebesar 26 responden atau $14,4 \%$.

\begin{tabular}{clrr}
$\begin{array}{c}\text { Tabel 5. Distribusi } \\
\text { Berdasarkan } \\
\text { Trauma Kepala }\end{array}$ & Outcome & $\begin{array}{r}\text { Responden } \\
\text { Pasien }\end{array}$ \\
\hline Variabel & \multicolumn{1}{c}{ Klasifikasi } & \multicolumn{1}{c}{ n } & $\%$ \\
\hline & $\begin{array}{l}\text { Good recovery } \\
\text { Moderate }\end{array}$ & 0 & 0 \\
Outcome & $\begin{array}{l}\text { Disability } \\
\text { Pasien }\end{array}$ & & 20 \\
Trauma & $\begin{array}{l}\text { Severe Disability } \\
\text { Persisten }\end{array}$ & 54 & 30 \\
Kepala & $\begin{array}{r}\text { Vegetative State } \\
\text { Death }\end{array}$ & 3 & 2 \\
& 88 & 48 \\
\hline
\end{tabular}


Dari tabel 5 diperoleh hasil bahwa hampir setengahnya responden sebesar 88 atau $48 \%$ death, sedangkan tak satu pun responden dengan klasifikasi good recovery.

Tabel 6. Uji Somers'd Hubungan Antara Scoring REMS dengan outcome Pasien Trauma Kepala

\begin{tabular}{lcccc}
\hline \multicolumn{3}{c}{ Uji Statistik Variabel } & Nilai & Signifikansi \\
\hline $\begin{array}{l}\text { Scoring } \\
\text { outcome }\end{array}$ & REMS & dengan & & \\
kepala & & trauma & 0,310 & 0,000 \\
\hline
\end{tabular}

Tabel 6 Uji Somers'd terlihat bahwa nilai signifikansi diperoleh nilai 0,000 , artinya ada hubungan antara scoring REMS dengan outcome pasien trauma kepala. Nilai somers' $d=0,310$, nilai ini menunjukkan tingkat hubungan antar variabel terbilang sedang. Arah hubungan yang positif ini berarti bahwa tingginya scoring REMS diikuti dengan perburukan outcome pasien trauma kepala.

Tabel 7. Uji Spearman Hubungan antara GCS dengan Outcome Pasien Trauma Kepala

\begin{tabular}{|c|c|c|}
\hline Uji Statistik Variabel & Nilai & Signifikansi \\
\hline $\begin{array}{l}\text { GCS dengan outcome } \\
\text { pasien trauma kepala }\end{array}$ & $-0,488$ & 0,000 \\
\hline
\end{tabular}

Tabel 7 Hasil uji spearman terlihat bahwa nilai signifikansi diperoleh nilai 0,000 , artinya ada hubungan antara GCS dengan outcome pasien trauma kepala. Nilai spearman rho $(r)=-0488$, nilai ini menunjukkan tingkat hubungan dalam kategori sedang. Arah hubungan yang negatif ini berarti bahwa semakin rendah nilai GCS, semakin tinggi risiko mendapatkan outcome buruk pada pasien trauma kepala.

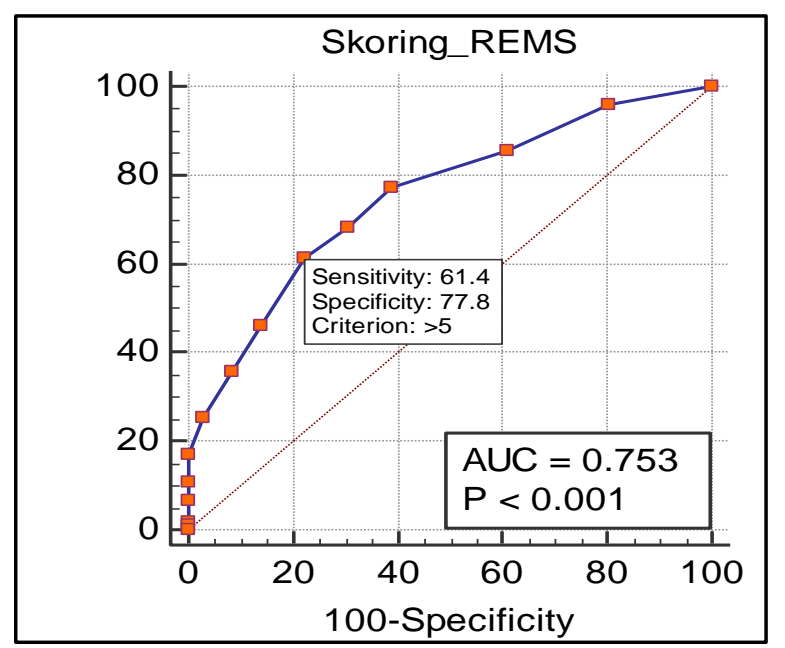

Gambar 1. Grafik ROC REMS terhadap Outcome Pasien Trauma Kepala
Gambar 1 menunjukkan bahwa kurva ROC yang dihasilkan dari berbagai nilai cut of point. Dapat diketahui bahwa kurva ROC berada di atas garis referensi. Nilai AUC yang dihasilkan yaitu sebesar 0,753 sehingga berdasarkan nilai AUC tersebut tingkat ketepatan prediksi scoring REMS pada klasifikasi baik.

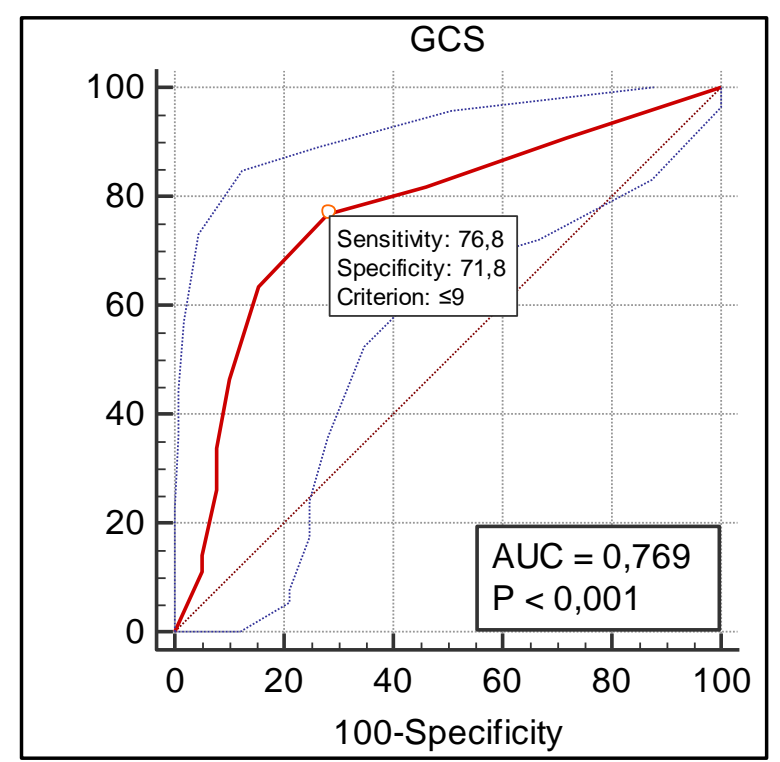

Gambar 2. Grafik ROC GCS terhadap Outcome Pasien Trauma Kepala

Gambar 2 menunjukkan bahwa kurva ROC yang dihasilkan dari berbagai nilai cut of point. Dapat diketahui bahwa kurva ROC berada di atas garis referensi. Nilai AUC yang dihasilkan yaitu sebesar 0,769 sehingga berdasarkan nilai AUC tersebut tingkat ketepatan prediksi GCS pada klasifikasi baik.

\section{PEMBAHASAN}

Berdasarkan hasil penelitian didapatkan hampir seluruhnya responden yaitu 128 (71\%) adalah berjenis kelamin laki-laki. Hasil ini hampir sama dengan penelitian yang dilakukan oleh Hartoyo, Raharjo, \& Budiyati (2011) didapatkan $75,4 \%$ responden berjenis kelamin laki-laki (Hartoyo, Raharjo, \& Budiyati, 2011). Faktor yang mungkin menjadi penyebab tingginya trauma kepala sedang-berat pada lakilaki di antaranya adalah aktivitas fisik maupun pekerjaan yang lebih berisiko dari perempuan. Namun menurut Marcolini, Albrecht, Sethuraman, \& Napolitano (2018) tingginya kejadian trauma kepala pada laki-laki bukan hanya karena aktivitas fisik dan pekerjaan saja, ada faktor hormonal pada laki-laki yang akan memicu stres dan mengakibatkan perilaku berisiko terjadinya trauma kepala seperti minum 
alkohol saat mengendarai kendaraan bermotor (Marcolini, Albrecht, Sethuraman, \& Napolitano, 2018).

Hasil penelitian ini menunjukkan bahwa trauma kepala sedang-berat paling banyak dialami oleh kelompok usia 16-25 tahun. Temuan ini sesuai dengan hasil temuan penelitian sebelumnya yang menunjukkan kelompok usia 15-24 tahun merupakan kelompok terbanyak mengalami trauma kepala, di mana kelompok ini merupakan kelompok dewasa muda yang memiliki produktivitas dan aktivitas yang tinggi (Lisnawa, et al., 2012). Kecelakaan kendaraan bermotor adalah penyebab trauma kepala paling umum pada kelompok umur 15-19 tahun dan 2024 tahun (Peeters, et al., 2015). Tingginya angka kejadian trauma kepala pada kelompok usia ini akibat kecelakaan lalu lintas dimungkinkan oleh karena tingginya mobilitas dan perkembangan psikologis, dimana usia dewasa muda perkembangan psikologis yang belum stabil sehingga sering gagal mengendalikan emosi. Keadaan ini menyebabkan kewaspadaan yang kurang dalam mengemudikan kendaraan bermotor.

Berdasarkan jenis pekerjaan, dalam penelitian ini didapatkan pekerjaan terbanyak adalah karyawan swasta sejumlah 66 responden $(36 \%)$. Hasil penelitian ini agak berbeda dengan hasil penelitian oleh Krisandi, Utomo, \& Indriati (2011) bahwa jenis pekerjaan responden trauma kepala adalah pelajar/mahasiswa (Krisandi, Utomo, \& Indriati, 2011). Dari hasil penelitian dan fakta penelitian sebelumnya dapat di asumsikan bahwa jenis pekerjaan mempunyai keterkaitan dengan kejadian trauma kepala, hal ini bisa dilihat dari faktor penyebab trauma kepala pada penelitian ini terbanyak adalah kecelakaan lalu lintas (86\%). Jadi dapat disimpulkan bahwa semakin sering pekerjaan yang membutuhkan aktivitas di jalan seperti mengendarai sepeda motor, mobil, becak maupun pejalan kaki semakin tinggi pula kemungkinan terjadinya trauma kepala.

Hasil analisis bivariat menggunakan uji Somers'd didapatkan bahwa p-value sebesar 0,000 , di mana nilai Somers' $d=0,310$ artinya antara scoring REMS dan outcome pasien trauma kepala pada tingkat hubungan sedang. Melihat hasil Somers'd bernilai positif, hubungan antara scoring REMS dengan outcome pasien trauma kepala bersifat searah, artinya semakin tinggi scoring REMS yang diperoleh semakin buruk outcome pasien trauma kepala. Hasil serupa diperoleh dari penelitian oleh Imhoff, et al (2014) yang menyebutkan terdapat hubungan scoring REMS dengan mortalitas di rumah sakit pada populasi trauma. Setiap peningkatan 1 nilai scoring REMS dikaitkan dengan peningkatan mortalitas di rumah sakit. Meskipun awalnya scoring REMS tidak dirancang untuk populasi trauma, namun scoring REMS ditemukan sebagai prediktor kuat mortalitas di rumah sakit untuk populasi trauma. REMS memiliki kinerja yang mirip dengan Revised Trauma Score (RTS) dan mengungguli beberapa scoring trauma yang digunakan sebelumnya seperti Injury Severity Score (ISS) dan Shock Indeks (SI). Penelitian oleh Alter, Infinger, Swanson, \& Studnek (2017), bahwa scoring REMS berkorelasi dengan angka morbiditas dan mortalitas. Ini menunjukkan bahwa scoring REMS mungkin berguna dalam mengevaluasi perubahan klinis selama di IGD maupun di ruang perawatan pasien.

Adanya kesamaan hasil penelitian ini dengan sebelumnya dimungkinkan karena populasi responden yang digunakan hampir sama yaitu pasien trauma. Walaupun pada penelitian ini lebih fokus pada trauma kepala, namun peneliti mengasumsikan tak ada perbedaan yang berarti hasil pengukuran parameter scoring REMS di antara pasien akibat trauma. Selanjutnya perbedaan metodologi yang digunakan antara penelitian ini dengan kedua penelitian sebelumnya juga tidak memberikan perbedaan hasil yang signifikan. Hal ini dimungkinkan bahwa tingkat akurasi yang tinggi pengukuran parameter dalam scoring REMS saat pasien masuk IGD.

Hasil penelitian didapatkan bahwa GCS memiliki hubungan yang signifikan dengan outcome pasien trauma kepala. Hal ini dapat dilihat dari nilai $p$-value $=0,000$ dan koefisiensi korelasi spearman $=0,488$ yang berarti bahwa GCS berhubungan dengan outcome pasien trauma kepala dengan kekuatan hubungan sedang. Arah hubungan yang negatif ini berarti bahwa semakin rendah nilai GCS, semakin tinggi risiko mendapatkan outcome buruk pada pasien trauma kepala.

Hasil penelitian ini hampir sama dengan hasil penelitian oleh Irawan, dkk (2017) yang menyebutkan GCS memiliki korelasi bermakna dalam menentukan tingkat disabilitas pasien trauma kepala ( $p$-value $=0,046$ ). Penilaian awal menggunakan GCS dapat memprediksi tingkat disabilitas pasien trauma kepala saat keluar dari rumah sakit. Penelitian lain yang mendukung hasil penelitian ini yaitu penelitian yang dilakukan oleh Sasmito, Wihastuti, \& Kristianto (2017) yang menyebutkan bahwa ada perubahan signifikan secara statistik antara skor GCS dengan mortalitas pasien cedera kepala. Dari penelitian ini juga didapatkan sebagian besar 
pasien cedera kepala memiliki skor GCS 10 atau bahkan $<10$ dan memiliki outcome pasien cedera kepala yang buruk. Selain itu juga ditemukan bahwa outcome pasien cedera kepala secara progresif akan menurun jika skor GCS yang sudah rendah.

Adanya kemiripan hasil penelitian ini dengan penelitian-penelitian sebelumnya dimungkinkan karena faktor neurologis yang tercakup dalam penilaian GCS (respon membuka mata, verbal dan motorik) benar-benar mampu mendeteksi perburukan pasien trauma kepala. Disamping itu GCS merupakan instrumen standar yang dapat digunakan untuk mengukur derajat dan penatalaksanaan selanjutnya pasien trauma kepala di beberapa rumah yang belum tersedia pemeriksaan CT scan.

GCS juga digunakan sebagai acuan pengobatan dan dasar pembuatan keputusan klinis umum untuk pasien. Selain mudah dilakukan, GCS juga memiliki peranan penting dalam memprediksi risiko kematian di awal trauma. Penilaian GCS bergantung pada respon serebrum terhadap rangsangan aferen. Variasi dari nilai GCS disebabkan oleh gangguan fungsi serebrum atau gangguan di batang otak yang mempengaruhi jalannya rangsangan ke hemisfer serebrum (Irawan, et al., 2017). Hal ini memperkuat bahwa GCS merupakan standar baku penilaian awal pasien trauma kepala di rumah sakit yang belum tersedia pemeriksaan CT scan.

Berdasarkan grafik ROC menunjukkan REMS memiliki performa yang baik untuk prediksi outcome trauma kepala di IGD RSUD dr. Soedono Madiun dengan nilai AUC di 0,753. Hasil ini hampir sama dengan penelitian sebelumnya yang menunjukkan performa baik bahkan sangat baik. Imhoff, et al (2014) yang meneliti scoring REMS untuk prediksi mortalitas pada populasi trauma menemukan nilai AUC 0,91 atau performa baik. Najafi, Zakeri, \& Mirhaghi (2018) juga meneliti scoring REMS untuk prediksi outcome pada populasi trauma menemukan nilai AUC 0,92 atau performa sangat baik. Nilai ini berbeda dari penelitian Hung, et al (2017)yang menyebutkan prediksi mortalitas pasien sepsis di IGD mendapatkan AUC sebesar 0,67 atau performa cukup.

Seperti yang dapat dilihat, adanya sedikit perbedaan berbagai penelitian dimungkinkan karena perbedaan dalam metodologi penelitian yang meliputi desain, populasi maupun tempat penelitian. Menurut Nakhjavan-shahraki, et al (2017) sistem scoring dikembangkan dan difungsikan sesuai dengan kondisi klinis pasien, yang meliputi: sistem fisiologis, anatomi maupun trauma. Dari hasil penelitian maupun teori yang disajikan disimpulkan bahwa ketepatan metodologi penelitian dan sistem scoring yang digunakan dimungkinkan akan meningkatkan nilai prediktif sistem scoring yang diteliti.

Nilai cut of point optimal $>5$ (risiko sedang) digunakan untuk memprediksi outcome pasien trauma kepala di IGD dengan sensitivitas 61,38\%, spesifisitas, 77,78\%. Hasil ini tidak jauh berbeda dari hasil penelitian oleh Park, et al (2017) yang memperoleh cut off point optimal 7 (risiko sedang) dengan sensitivitas 84,4\%, spesifisitas 77,3\%, juga Hung, et al (2017) memperoleh nilai cut off point optimal 7 (risiko sedang) dengan sensitivitas 64,29\%, spesifisitas $72 \%$. Adanya kemiripan nilai cut off point optimal yang diduga skor awal berisiko dan berdampak pada outcome yang buruk ini menunjukkan bahwa parameter REMS mampu memprediksi outcome pasien trauma kepala pada semua penelitian.

Performa diskriminasi GCS pada penelitian ini masuk dalam kategori baik, ditunjukkan dengan nilai AUC sebesar 0,769 ( $95 \%$ CI, 0,701 to 0,828 ) dengan $\mathrm{p}$ value sebesar 0,001 . Nilai AUC pada penelitian ini hampir sama dengan temuan pada penelitian sebelumnya. Pada penelitian Ghelichkhani, Esmaeili, Hosseini, \& Seylani (2018) yang meneliti perbedaan GCS dan FOUR Score terhadap prediksi mortalitas di IGD mendapatkan nilai AUC sebesar 0.87 (95\% CI: 0.77 to 0.98 ) atau dalam kategori prediksi baik.

Kemiripan nilai performa diskriminasi ini dapat dijelaskan karena jenis kasus yang digunakan dalam penelitian ini dengan sebelumnya sama terfokus pada pasien dengan trauma kepala. Pada pasien trauma kepala assesment neurologis seperti GCS merupakan elemen essensial dalam skor peringatan dini. Hal ini sesuai pendapat Shalaby (2019) yang menyatakan bahwa penilaian level of consciousness (LOC) atau derajat kesadaran merupakan indikator kunci menentukan prognosis dan outcome pada pasien trauma kepala.

Hasil cut of point didapatkan pada titik $\leq 9$ (cedera kepala sedang-berat) menunjukkan analisis sensitivitas $76,8 \%$, spesifisitas $71,8 \%$ dan akurasi $74,3 \%$. Hampir sama dengan penelitian Sobuwa, et al (2014) bahwa outcome yang buruk pada pasien trauma kepala banyak terjadi pada skor GCS $\leq 8$. Skor GCS yang lebih rendah pada pasien trauma kepala berhubungan dengan mortalitas di rumah sakit. 


\section{SIMPULAN}

Penelitian ini menemukan bahwa kemampuan REMS dan GCS memprediksi outcome pasien trauma kepala menunjukkan

\section{DAFTAR PUSTAKA}

Alter, S. M., Infinger, A., Swanson, D., \& Studnek, J. R. (2017). Evaluating clinical care in the prehospital setting: Is Rapid Emergency Medicine Score the missing metric of EMS? American Journal of Emergency Medicine, 35(2), 218-221. https://doi.org/10.1016/j.ajem.2016.10.047

De Oliveira Thais, M. E. R., Cavallazzi, G., Formolo, D. A., De Castro, L. D. Á., Schmoeller, R., Guarnieri, R., ... Walz, R. (2014). Limited predictive power of hospitalization variables for long-term cognitive prognosis in adult patients with severe traumatic brain injury. Journal of Neuropsychology, $\quad 8(1), \quad$ 125-139. https://doi.org/10.1111/jnp.12000

Ghelichkhani, P., Esmaeili, M., Hosseini, M., \& Seylani, K. (2018). Glasgow Coma Scale and FOUR Score in Predicting the Mortality of Trauma Patients; a Diagnostic Accuracy Study. Emergency; 6(1), 1-7.

Hartoyo, M., Raharjo, S. S., \& Budiyati. (2011). Predictor's Factors of Mortality of Patients Suffering from Severe Head Injury in Emergency Department at General Hospital Tugurejo Semarang Prediktor Mortalitas Penderita Cedera Kepala Berat Di Instalasi Gawat Darurat RSU Tugurejo Semarang Mugi Hartoyo, Jurnal Riset Kesehatan, 1(3), 175-182.

Hung, S., Ng, C., Kuo, C., Ning, Z., Goh, L., Huang, H., ... Seak, C. (2017). Comparison of the Mortality in Emergency Department Sepsis Score, Modified Early Warning Score , Rapid Emergency Medicine Score and Rapid Acute Physiology Score for predicting the outcomes of adult splenic abscess patients in the emergency department, PLoS One, 12(11), e0187495.1-10.

Imhoff, B. F., Thompson, N. J., Hastings, M. A., Nazir, N., Moncure, M., \& Cannon, C. M. (2014). Rapid Emergency Medicine Score (REMS) in the trauma population: A retrospective study. BMJ Open, 4(5), 1-7. https://doi.org/10.1136/bmjopen-2013004738

In-suk, B., Hyoung-joon, C., Hyeong-joong, Y., performa baik. Sehingga keduanyabisa dipertimbangkan digunakan sebagai sistem deteksi dini atau Early Warning Score Sistem (EWSS) pada pasien trauma kepala di IGD.

\& Kyu-sun, C. (2020). Using components of the Glasgow coma scale and Rotterdam CT scores for mortality risk strati fi cation in adult patients with traumatic brain injury: A preliminary study. Clinical Neurology and Neurosurgery, 188 (September 2019), 1-6. https://doi.org/10.1016/j.clineuro.2019.105 599

Irawan, H., Setiawan, F., Dewi, \& Dewanto, G. (2017). Perbandingan Glasgow Coma Scale dan Revised Trauma Score dalam Memprediksi Disabilitas Pasien Trauma Kepala di Rumah Sakit Atma Jaya. Majalah Kedokteran Indonesia, 60 (March).

Krisandi, E., Utomo, W., \& Indriati, G. (2011). Gambaran Status Kognitif Pada Pasien Cedera Kepala yang Telah di izinkan pulang di RSUD Arifin Achmad Pekanbaru. [Skripsi]. Riau: Universitas Riau.

Lecky, F. E., Roberts, I., \& Maas, A. I. R. (2017). Differential effects of the Glasgow Coma Scale Score and its Components: an analysis of 54069 patients with traumatic brain injury . Injury, 48(5), 1932-1943. https://doi.org/10.1016/j.injury.2017.05.038

Lisnawa, Kwandou, L., Akbar, M., Muis, A., Kaelan, C., \& Patellongi, I. (2012). Hubungan skor Cognitive Test for Delirium (CTD) dengan luaran berdasarkan Glasgow Outcome Scale (GOS) pada penderita cedera kepala tertutup ringan-sedang. Jurnal Sains \& Teknologi Kesehatan, 2(2), 163-169.

Marcolini, E. G., Albrecht, J. S., Sethuraman, K. N., \& Napolitano, L. M. (2018). Gender Disparities in Trauma Care: How Sex Determines Treatment, Behavior, andOutcome. Anesthesiology Clinics, 37(1), 107-117.

https://doi.org/10.1016/j.anclin.2018.09.007

Miller, R. T., Nazir, N., McDonald, T., \& Cannon, C. M. (2017). The modified rapid emergency medicine score: A novel trauma triage tool to predict in-hospital mortality. Injury, 48(9), 1870-1877. 
https://doi.org/10.1016/j.injury.2017.04.048

Mulyono, D., Nurdiana, \& Kapti, R. E. (2019). Performa Rapid Emergency Medicine Score dalam Memprediksi Outcome Pasien Trauma Kepala di Instalasi Gawat Darurat Validation of Rapid Emergency Medicine Score in Predicting the Outcome of Head Injury Patient in the Emergency Department. Jurnal Kedokteran Brawijaya, 30(4), 302-308.

Najafi, Z., Zakeri, H., \& Mirhaghi, A. (2018). The accuracy of acuity scoring tools to predict 24 -h mortality in traumatic brain injury patients: A guide to triage criteria. International Emergency Nursing, 36(May 2017), 27-33. https://doi.org/10.1016/j.ienj.2017.08.003

Nakhjavan-shahraki, B., Baikpour, M., Yousefifard, M., Nikseresht, Z. S., Razaz, J. M., Faridaalaee, G., ... Hosseini, M. (2017). Rapid Acute Physiology Score versus Rapid Emergency Medicine Score in Trauma Outcome Prediction; a Comparative Study. Emergency, 5(1), 165 172.

Olsson, T., Terent, A., \& Lind, L. (2004). Rapid Emergency Medicine Score can predict long-term mortality in nonsurgical emergency department patients. Academic Emergency Medicine: Official Journal of the Society for Academic Emergency Medicine, 11(10), 1008-1013. https://doi.org/10.1197/j.aem.2004.05.027

Park, H. O., Kim, J. W., Kim, S. H., Moon, S. H., Byun, J. H., Kim, K. N., ... Choi, J. Y. (2017). Usability verification of the Emergency Trauma Score (EMTRAS) and Rapid Emergency Medicine Score (REMS) in patients with trauma. Medicine, 1-5.

Peeters, W., van den Brande, R., Polinder, S.,
Brazinova, A., Steyerberg, E. W., Lingsma, H. F., \& Maas, A. I. R. (2015). Epidemiology of traumatic brain injury in Europe. Acta Neurochirurgica (1st ed., Vol. 157). Elsevier B.V. https://doi.org/10.1007/s00701-015-2512-7

Saiegh, F. Al, Philipp, L., Mouchtouris, N., Chalouhi, N., Khanna, O., Shah, S. O., \& Jallo, J. (2020). Comparison of Outcomes of Severe Traumatic Brain Injury in 36,929 Patients Treated with or without Intracranial Pressure Monitoring in a Mature Trauma System. World Neurosurgery. https://doi.org/10.1016/j.wneu.2020.01.070 Sasmito, N., Wihastuti, T., \& Kristianto, H. (2017). Analisis faktor yang berhubungan dengan. J.K Msencephalon, 3(2), 91-104.

Shalaby, S. (2019). Full Outline of UnResponsiveness Scale ( FOUR ) Versus Modified Glasgow Coma Scale ( GCS ) in Predicting Discharge Outcomes of Altered Consciousness Patients, (January). American Journal of Nursing Research, 7(1), 79-86. https://doi.org/10.12691/ajnr-7-1-11

Sobuwa, S., Hartzenberg, H. B., Geduld, H., \& Uys, C. (2014). Predicting outcome in severe traumatic brain injury using a simple prognostic model. South African Medical Journal, 104(7), 492-494. https://doi.org/10.7196/samj.7720

Teasdale, G., Maas, A., Lecky, F., Manley, G., Stocchetti, N., \& Murray, G. (2014). The Glasgow Coma Scale at 40 years : standing the test of time. Lancet Neurol, 13 (August), 844-854. https://doi.org/10.1016/S1474 4422(14)70120-6 